\title{
Combined vitrectomy, near-confluent endolaser, bevacizumab and cyclophotocoagulation for neovascular glaucoma
}

Strzalkowski P., ${ }^{1}$ Strzalkowska A., ${ }^{1}$ Göbel W., ${ }^{1}$ Ach T., ${ }^{1}$ Loewen N.A., ${ }^{1}$ Hillenkamp J. ${ }^{1}$

1. Department of Ophthalmology, University Hospital Würzburg

\section{Correspondence to:}

Piotr Strzalkowski, Department of Ophthalmology, University Hospital Würzburg, Josef-Schneider-Straße 11, 97080 Würzburg, Germany; strzalkows_p@ukw.de

ORCID iD: https://orcid.org/0000-0003-2063-5743

\section{Financial disclosures:}

Strzalkowski P.: N

Strzalkowska A.: N

Göbel W.: N

Ach T.: R: Roche, Alimera, Allergan, Novartis.

Loewen N.A.: R: Neomedix Inc.

Hillenkamp J.: N 
medRxiv preprint doi: https://doi.org/10.1101/2020.01.19.20017889; this version posted January 27, 2020. The copyright holder for this preprint (which was not certified by peer review) is the author/funder, who has granted medRxiv a license to display the preprint in

All rights reserved. No reuse allowed without permission.

\begin{abstract}
Purpose: Evaluated the safety and efficacy of an integrative surgical approach to neovascular glaucoma (NVG).

Methods: Consecutive interventional case series of NVG with one-year follow-up. Eyes underwent pars plana vitrectomy, near-confluent panretinal photocoagulation, intravitreal bevacizumab, and transscleral cyclophotocoagulation. Phakic eyes underwent concomitant cataract surgery. Best-corrected visual acuity (BCVA, logMAR), intraocular pressure (IOP, mmHg), glaucoma medication score (GMS), visual analog pain scale (VAPS, 0-10) were recorded at baseline, and 1, 3, 6 and 12 months. Blind eyes were excluded.
\end{abstract}

Results: 83 eyes of 83 patients (53 male, 30 female, mean age $74.6 \pm 11.6$ years) were included and 53 completed a one-year follow-up. NVG underlying conditions included retinal vein occlusion $(n=41)$, proliferative diabetic retinopathy $(n=25)$, central retinal artery occlusion $(n=10)$, and ocular ischemic syndrome $(n=6)$. Mean IOP decreased postoperatively from $46.0 \pm 10.3 \mathrm{mmHg}$ to $14.2 \pm 8.9 \mathrm{mmHg}(p<0.001)$, GMS from 4.8 to $1.8(p<0.001)$ and VAPS from 6 to 0 . BCVA was unchanged. All postoperative complications had resolved at 1 month postop. 26 eyes did not require additional surgical treatment during follow-up.

Conclusions: A single, comprehensive surgery session was able to significantly lower $I O P$, reduce GMS and control pain.

\title{
Keywords
}

Neovascular glaucoma, integrative surgical approach, iris neovascularization. 
medRxiv preprint doi: https://doi.org/10.1101/2020.01.19.20017889; this version posted January $27,2020$. The copyright holder for this preprint (which was not certified by peer review) is the author/funder, who has granted medRxiv a license to display the preprint in

All rights reserved. No reuse allowed without permission.

\section{Introduction}

An estimated 75,000 to 113,000 individuals are affected by neovascular glaucoma (NVG) in the European Union ${ }^{1}$. A variety of ocular and systemic conditions can cause retinal hypoxia that eventually leads to neovascularization of the iris (NVI) and the angle (NVA). NVG carries a poor prognosis for both ocular and general health: at five years, the failure rate of glaucoma drainage implants to control intraocular pressure (IOP) are near $80 \%{ }^{2}$ and of cyclophotocoagulation near $65 \%$, respectively; remarkably, patient survival itself is reduced by $40 \%$ at five years ${ }^{3}$.

Neovascularization is the formation of abnormal blood vessels in an abnormal location. In NVG, vessels and fibrovascular membranes block aqueous humor outflow in the angle of the anterior chamber. The most common predisposing ocular conditions for NVG are retinal ischemia caused by central retinal vein occlusion (CRVO), proliferative diabetic retinopathy (PDR), central retinal artery occlusion (CRAO), and ocular ischemic syndrome ${ }^{1}$. Carotid artery obstructive disease and fistulas are additional, extraocular vascular causes for retinal ischemia ${ }^{1}$. Early recognition and therapy are imperative to prevent aggressive evolution with severe vision loss and intractable pain. In the past, treatment steps have been mostly applied sequentially. These include IOP lowering (topical and systemic glaucoma medications, glaucoma drainage implants, cyclodestruction) ${ }^{4-8}$, anti-inflammatory treatment (topical or intraocular steroids) as well as treatment of retinal ischemia (panretinal photocoagulation (PRP) ${ }^{9,10}$, and vascular endothelial growth factor (VEGF) inhibitors ${ }^{11-13}$ ) as an adjuvant therapy. Other studies indicate that vitrectomy with PRP and silicone oil tamponade may reduce IOP in eyes with NVG ${ }^{14,15}$. Although NVG can quickly lead to a blind and painful eye that requires enucleation ${ }^{16}$, there is no general consensus on how to best initiate treatment.

We evaluated the safety and efficacy of an integrative combined surgical approach for evolving NVG that combined pars plana vitrectomy, near-confluent full-scatter panretinal photocoagulation, intravitreal bevacizumab, and transscleral cyclophotocoagulation in one operation. Phakic eyes underwent concomitant cataract surgery. We hypothesized that this approach would prevent or slow NVG progression when applied at first sight of neovascularization and IOP elevation $>21 \mathrm{mmHg}$. 
medRxiv preprint doi: https://doi.org/10.1101/2020.01.19.20017889; this version posted January $27,2020$. The copyright holder for this preprint (which was not certified by peer review) is the author/funder, who has granted medRxiv a license to display the preprint in

All rights reserved. No reuse allowed without permission.

\section{Methods}

\section{Study design}

Our study was reviewed and approved by the Ethics Committee of the University of Würzburg, and performed in accordance with the ethical standards set forth in the 1964 Declaration of Helsinki and the Health Insurance Portability and Accountability Act.

This consecutive interventional case series included patients who met the following inclusion criteria: 1) NVI or NVA, 2) IOP > $21 \mathrm{mmHg}, 3$ ) visual acuity of at least light perception and 4) above or equal to 18 years of age. All patients were treated at the University Eye Hospital in Würzburg, Germany, between October 2014 and December 2018. We recorded best-corrected visual acuity (BCVA, logMAR), intraocular pressure (IOP, mmHg), glaucoma medication score (GMS) ${ }^{17}$, visual analog pain scale (VAPS, 0-10) at baseline and at visits at 1, 3, 6 and 12 months.

Hypotony was defined as IOP $\leq 5 \mathrm{mmHg}$ with hypotonous maculopathy, choroidal folds, or optic neuropathy ${ }^{18}$. Phthisis bulbi ${ }^{19}$ was defined as IOP $\leq 5 \mathrm{mmHg}$ in a shrunken eye with worse than hand motion vision with or without pain containing atrophic and disorganized intraocular structures. Success was defined as IOP $\leq 21$ $\mathrm{mmHg}$ or IOP reduction $\geq 30 \%$ from baseline, with or without glaucoma medication and without vision loss ${ }^{20}$.

Eyes with no light perception and patients with a history of glaucoma other than NVG were excluded. All patients underwent decimal visual acuity testing which was converted to a logMAR scale. Counting finger (CF), hand movements (HM), light perception (LP), and no light perception (NLP) were converted into logMAR units 1.9, $2.3,2.7$, and 3.0, respectively ${ }^{21-23}$.

\section{Surgical technique}

All eyes underwent standard 3-port 23 gauge pars plana vitrectomy with detachment of the posterior vitreous if not already present, near-confluent full-scatter panretinal photocoagulation applied under indentation in all four quadrants from the vascular arcades to the ora serrata, intravitreal $0,1 \mathrm{~mL}$ of bevacizumab (Avastin $₫ 25$ $\mathrm{mg} / 1 \mathrm{~mL}$, Roche Pharma, Switzerland), transscleral cyclophotocoagulation (810 nm diode laser, 360 degrees treatment to pop threshold with 20 spots and leaving out 3 and 9 o'clock), and air tamponade. Phakic eyes underwent concomitant cataract 
medRxiv preprint doi: https://doi.org/10.1101/2020.01.19.20017889; this version posted January 27, 2020. The copyright holder for this preprint (which was not certified by peer review) is the author/funder, who has granted medRxiv a license to display the preprint in

All rights reserved. No reuse allowed without permission.

surgery using a bag-in-the-lens IOL (type 89F; Morcher, Stuttgart, Germany) to reduce the incidence of posterior capsular opacification and posterior synechiae ${ }^{24,25}$. The operation was carried out either with a retrobulbar block or general anesthesia.

\section{Retreatment}

At follow-up, all eyes with elevated IOP were treated following an escalation scheme. First, glaucoma medications were increased to what was maximally tolerated. Eyes were then treated with transscleral cyclophotocoagulation $(810 \mathrm{~nm}$ diode laser, 360 degrees treatment to pop threshold with 20 spots). Eyes that failed to respond to cyclophotocoagulation with a significant IOP reduction and had retained ambulatory visual acuity underwent tube shunt surgery. Repeated vitrectomy including fill-in panretinal photocoagulation, transscleral cyclophotocoagulation and intravitreal bevacizumab was applied in eyes with elevated IOP and dense vitreous hemorrhage. Fill-in panretinal photocoagulation was applied in these eyes when panretinal photocoagulation had not been completed in the first vitrectomy due to extensive intraretinal hemorrhage in ischemic retinal disease. Further intravitreal injections of VEGF inhibitors were only applied for clinically significant non-ischemic macular edema and $B C V A \geq 1.1 \log M A R$.

\section{Statistical Methods}

Data analysis was performed using Statistica 13.1 (Tulsa, Oklahoma, United States). Categorical variables were described by the frequency of observations. Continuous variables were described as mean with standard deviation (SD) or median with range (minimum - maximum). Friedman test and Wilcoxon signed-rank test were used to compare data measured on an ordinal scale and continuous variables with non-normal distribution. Evaluation of data normality was performed using the Shapiro-Wilk test. Welch's t-test for unequal variances was used for IOP between pain versus no-pain group comparison. Kaplan-Meier curve and log-rank test were used for success analysis. P-values $<0.05$ were considered significant. 
medRxiv preprint doi: https://doi.org/10.1101/2020.01.19.20017889; this version posted January $27,2020$. The copyright holder for this preprint (which was not certified by peer review) is the author/funder, who has granted medRxiv a license to display the preprint in

All rights reserved. No reuse allowed without permission.

\section{Results}

83 eyes of 83 patients (53 male, 30 female, mean $74.6 \pm 11.6$ years) were included of which 1 month, 3 months, 6 months and one year follow up completed 81 , 71,62 and 53 eyes, respectively. Conditions that lead to NVG included CRVO $(n=41)$, $\operatorname{PDR}(n=25), \operatorname{CRAO}(n=10)$, and ocular ischemic syndrome $(n=7)$.

Mean logMAR BCVA was $2.0 \pm 0.7$ at baseline and $1.8 \pm 0.8$ at twelve months ( $p=0.47$, Fig.1). Three eyes worsened from LP to NLP at one week, six months, and twelve months, respectively. At baseline, 32.5\% (27/83) of patients and at 12 months $47.2 \%(25 / 53)$ of patients had an ambulatory visual acuity ( $\geq \log$ MAR 1.7$)$, respectively. Only two patients presented at baseline with IOP $<30 \mathrm{mmHg}$.

IOP decreased significantly from the baseline of $46.0 \pm 10.3 \mathrm{mmHg}$ at one month $(18.8 \pm 9.9 \mathrm{mmHg})$, three months $(17.2 \pm 9.8 \mathrm{mmHg})$, six months $(14.7 \pm 8.1 \mathrm{mmHg})$, and twelve months (14.2 \pm 8.9 mmHg; $p<0.001$; Fig. 2). At one-year follow-up, 90.6\% $(n=48)$ of patients had an IOP $\leq 21 \mathrm{mmHg}$. IOP $\leq 5 \mathrm{mmHg}$ was found in $11.3 \%(\mathrm{n}=6)$ and tolerated without complications.

GMS decreased from 4.8 \pm 2.5 medications at baseline to $1.8 \pm 1.8(p<0.001$; Fig. 3) at twelve months. While $32.5 \%(n=27)$ of patients complained of ocular pain at baseline (VAPS: $6.3 \pm 1.6$ ) all patients were without pain at all follow-up visits. Patients with pain had a significantly higher baseline IOP of $49.2 \pm 7.9 \mathrm{mmHg}$ compared to patients without pain $44.5 \pm 11.1 \mathrm{mmHg}(p=0.027)$.

Early postoperative complications (day 1-4 weeks) included intraocular fibrin (56/83), hyphema (18/83), choroidal detachment (14/83), and corneal erosion (12/83) (Table 1). Late postoperative complications (> 1 months) included retinal detachment (3/83) and painless phthisis bulbi (4/83).

During one-year follow-up, retreatment was applied in $27 / 53$ eyes. $44.4 \%$ (12/27) underwent one additional cyclodestruction. Other re-treatments were vitrectomy (8/27), Baerveldt glaucoma drainage (5/27), trabeculectomy (1/27), and filtering bleb needling (1/27). 7.5\% (4/53) patients with a mean BCVA 1.1 $\pm 0.3 \log M A R$ received further anti-VEGF injections (4.0 \pm 0.8 injections).

$27.7 \%(23 / 83)$ patients were lost to follow-up and $8.4 \%$ (7/83) patients died during the one-year follow-up.

Kaplan-Meier analysis shows a probability of success of $65 \%$ at one year follow-up (Fig. 4). 
medRxiv preprint doi: https://doi.org/10.1101/2020.01.19.20017889; this version posted January $27,2020$. The copyright holder for this preprint (which was not certified by peer review) is the author/funder, who has granted medRxiv a license to display the preprint in

All rights reserved. No reuse allowed without permission.

\section{Discussion}

By 1871, NVG was known as "glaucoma haemorrhagicum et apoplecticum" and feared as a consequence of ischemia that quickly led to enucleation due to "hefty ciliary neuralgia" ${ }^{26}$. In 1963, using improved equipment, Weiss et al. found that emerging neovascularization and fibrovascular membranes of the iris and the angle could be observed well before the onset of advanced NVG ${ }^{27}$ hinting at a window to initiate treatment. Today, the ability to detect neovascularization early is complemented by better interventions that address both the underlying pathology and the elevated IOP. However, these interventions need to be implemented urgently because NVG continues to have a rapid evolution and a poor prognosis for both the eye and the patient ${ }^{3}$.

Addressing this need, our results show that the combined approach of lens extraction with bag-in-the-lens IOL, pars plana vitrectomy, near-confluent full-scatter panretinal photocoagulation between the vascular arcades and the ora serrata, intravitreal bevacizumab, and transscleral cyclophotocoagulation is a safe and effective treatment that can lower mean IOP from about 46 to near $14 \mathrm{mmHg}$ by post-op day one, reduce the number of glaucoma medications and control pain.

Retinal ischemia is the primary cause of neovascular glaucoma ${ }^{1,28}$. Accordingly, PRP is the standard of care to reduce posterior pole oxygen demand and angiogenic drive while vitrectomy is performed to increase the partial pressure of vitreous oxygen ${ }^{28-31}$. We performed lens extraction, pars plana vitrectomy, and endoscopic PRP because of significant media opacities and because endoscopic laser through the pars-plana approach facilitates the delivery of $360^{\circ}$ near-confluent peripheral retinal laser treatment out to the ora serrata. In our clinical experience, further progression of NVG with elevated IOP can be maintained by even relatively small areas of untreated ischemic retina. Therefore, we took great care to apply $360^{\circ} \mathrm{PRP}$ to near-confluence up to the ora serrata. Such extensive treatment would be more difficult to accomplish using standard externally delivered PRP.

In the healthy eye, the vitreous body and the iris-lens diaphragm form a relative diffusion barrier that maintains a higher oxygen partial pressure in the anterior chamber compared to the vitreous overlying the posterior pole. Concurrently, it reduces the diffusion of angiogenic mediators. Recreating a relative diffusion barrier after vitrectomy 
medRxiv preprint doi: https://doi.org/10.1101/2020.01.19.20017889; this version posted January $27,2020$. The copyright holder for this preprint (which was not certified by peer review) is the author/funder, who has granted medRxiv a license to display the preprint in

All rights reserved. No reuse allowed without permission.

${ }^{30}$ is beneficial and reduces the occurrence of $\mathrm{NVI}^{32}$. A barrier can be achieved with silicone oil ${ }^{33}$ that lessens the incidence of neovascular glaucoma ${ }^{33,34}$. Following this concept, Bartz-Schmidt et al. treated 32 NVG patients with pars plana vitrectomy, retinal and ciliary body photocoagulation, as well as silicone oil tamponade because eyes were left aphakic ${ }^{14}$. This approach controlled IOP in $72 \%$ of patients for at least one year. In our study, all eyes were pseudophakic and without silicone oil at the conclusion of the surgery, thereby negating the need for silicone oil as a diffusion barrier. We observed IOP control in 79,2\%, more eyes than reported by Bartz-Schmidt et al. ${ }^{14}$.

Our success rate of $65 \%$ defined as IOP $<22 \mathrm{mmHg}$, with or without glaucoma medication and without vision loss after one year follow-up is similar to success rates reported for glaucoma drainage devices which range from $62 \%$ to $66.7 \%{ }^{8,35-37}$. One study reported $73 \%$ success rate in 38 eyes treated with glaucoma drainage device and, in contrast to other studies ${ }^{8,35-37}$, with very few postoperative complications ${ }^{2}$. The integrative surgical approach presented here avoids tube-specific complications (e.g. tube exposure, retraction, corneal touch, obstruction) that can range from $13 \%$ to $26 \%$ in NVG over five years ${ }^{2,8,35-37}$.

Our approach delivers both retina and glaucoma treatment in a single surgical session and reduces the burden on the patient and health care system by simplifying postoperative care and follow up. It is worth noting that an IOP reduction could also be achieved without cyclodestruction applying only pars plana vitrectomy, lensectomy with a preserved anterior capsule, and panretinal endophotocoagulation. However, only 13 eyes were included and the mean preoperative IOP of $29 \mathrm{mmHg}$ was lower than in our study ${ }^{15}$. By contrast, treatment with anti-VEGF agents was insufficient as a primary therapy ${ }^{12,38}$, with failure rates up to $88 \%{ }^{38}$. Anti-VEGF agents may be best used as an adjuvant treatment ${ }^{13}$. Consistent with our findings, pars plana vitrectomy, endoscopic peripheral panretinal photocoagulation, and endocyclophotocoagulation (ECP) also led to an IOP reduction and seemed to be more effective compared to panretinal photocoagulation, intravitreal bevacizumab, pars plana vitrectomy, and filtration surgery or Ahmed valve placement, but in this study phthisis bulbi occurred in $7.4 \%$ of cases ${ }^{39}$.

Unsurprisingly, visual function remained poor in most eyes in our study. Although $67 \%$ of eyes were inflamed postoperatively, inflammation was transient and painless in all eyes. The observed high mortality rate is a reminder that any treatment 
medRxiv preprint doi: https://doi.org/10.1101/2020.01.19.20017889; this version posted January 27, 2020. The copyright holder for this preprint (which was not certified by peer review) is the author/funder, who has granted medRxiv a license to display the preprint in All rights reserved. No reuse allowed without permission.

strategy of NVG should ideally require as few surgical interventions and hospital visits as possible.

Our study has several limitations. Because the integrative surgical approach described here was the primary practice pattern, there was no control group. This limited us to an intragroup comparison of before versus after treatment data. As a retrospective study, in addition to informing on parameters and design of future prospective studies, it can only help to formulate, but not answer, hypotheses about associations between treatment and outcomes.

In conclusion, this study shows that NVG can be controlled by an integrative surgical approach delivered in a single session that combines cataract removal, pars plana vitrectomy, near-confluent full-scatter panretinal photocoagulation, intravitreal bevacizumab, and transscleral cyclophotocoagulation. This approach simplifies care and addresses multiple ophthalmic and patient-related challenges. 
medRxiv preprint doi: https://doi.org/10.1101/2020.01.19.20017889; this version posted January $27,2020$. The copyright holder for this preprint (which was not certified by peer review) is the author/funder, who has granted medRxiv a license to display the preprint in

All rights reserved. No reuse allowed without permission.

\section{References}

1. Havens SJ, Gulati V. Neovascular Glaucoma. Dev Ophthalmol. 2016;55:196-204.

2. Netland PA, Ishida K, Boyle JW. The Ahmed Glaucoma Valve in patients with and without neovascular glaucoma. J Glaucoma. 2010;19(9):581-586.

3. Blanc J-P, Molteno ACB, Fuller JR, Bevin TH, Herbison P. Life expectancy of patients with neovascular glaucoma drained by Molteno implants. Clin Experiment Ophthalmol. 2004;32(4):360-363.

4. Schlote T, Derse M, Rassmann K, Nicaeus T, Dietz K, Thiel HJ. Efficacy and safety of contact transscleral diode laser cyclophotocoagulation for advanced glaucoma. J Glaucoma. 2001;10(4):294-301.

5. Delgado MF, Dickens CJ, Iwach AG, et al. Long-term results of noncontact neodymium:yttrium-aluminum-garnet cyclophotocoagulation in neovascular glaucoma. Ophthalmology. 2003;110(5):895-899.

6. Oguri A, Takahashi E, Tomita G, Yamamoto T, Jikihara S, Kitazawa Y. Transscleral cyclophotocoagulation with the diode laser for neovascular glaucoma. Ophthalmic Surg Lasers. 1998;29(9):722-727.

7. Shchomak Z, Cordeiro Sousa D, Leal I, Abegão Pinto L. Surgical treatment of neovascular glaucoma: a systematic review and meta-analysis. Graefes Arch Clin Exp Ophthalmol. 2019;257(6):1079-1089.

8. Zhou M, Xu X, Zhang X, Sun X. Clinical Outcomes of Ahmed Glaucoma Valve Implantation With or Without Intravitreal Bevacizumab Pretreatment for Neovascular Glaucoma: A Systematic Review and Meta-Analysis. J Glaucoma. 2016;25(7):551-557.

9. Chuang L-H, Wang N-K, Chen Y-P, et al. Vitrectomy and panretinal photocoagulation reduces the occurrence of neovascular glaucoma in central retinal vein occlusion with vitreous hemorrhage. Retina. 2013;33(4):798-802.

10. Budzynski E, Smith JH, Bryar P, Birol G, Linsenmeier RA. Effects of photocoagulation on intraretinal PO2 in cat. Invest Ophthalmol Vis Sci. 2008;49(1):380-389.

11. Yazdani S, Hendi K, Pakravan M. Intravitreal bevacizumab (Avastin) injection for neovascular glaucoma. J Glaucoma. 2007;16(5):437-439.

12. Lüke J, Nassar K, Lüke M, Grisanti S. Ranibizumab as adjuvant in the treatment of rubeosis iridis and neovascular glaucoma--results from a prospective interventional case series. Graefes Arch Clin Exp Ophthalmol. 2013;251(10):2403-2413.

13. Olmos LC, Sayed MS, Moraczewski AL, et al. Long-term outcomes of neovascular glaucoma treated with and without intravitreal bevacizumab. Eye. 2016;30(3):463-472. 
medRxiv preprint doi: https://doi.org/10.1101/2020.01.19.20017889; this version posted January $27,2020$. The copyright holder for this preprint (which was not certified by peer review) is the author/funder, who has granted medRxiv a license to display the preprint in

All rights reserved. No reuse allowed without permission.

14. Bartz-Schmidt KU, Thumann G, Psichias A, Krieglstein GK, Heimann K. Pars plana vitrectomy, endolaser coagulation of the retina and the ciliary body combined with silicone oil endotamponade in the treatment of uncontrolled neovascular glaucoma. Graefes Arch Clin Exp Ophthalmol. 1999;237(12):969-975.

15. Kinoshita N, Ota A, Toyoda F, Yamagami H, Kakehashi A. Surgical results of pars plana vitrectomy combined with pars plana lensectomy with anterior capsule preservation, endophotocoagulation, and silicon oil tamponade for neovascular glaucoma. Clin Ophthalmol. 2011;5:1777-1781.

16. Setlur VJ, Parikh JG, Rao NA. Changing causes of enucleation over the past 60 years. Graefes Arch Clin Exp Ophthalmol. 2010;248(4):593-597.

17. Jacobi PC, Krieglstein GK. Trabecular aspiration. A new mode to treat pseudoexfoliation glaucoma. Invest Ophthalmol Vis Sci. 1995;36(11):2270-2276.

18. Abbas A, Agrawal P, King AJ. Exploring literature-based definitions of hypotony following glaucoma filtration surgery and the impact on clinical outcomes. Acta Ophthalmol. 2018;96(3):e285-e289.

19. Tan LT, Isa H, Lightman S, Taylor SR. Prevalence and causes of phthisis bulbi in a uveitis clinic. Acta Ophthalmol. 2012;90(5):e417-e418.

20. Shaarawy TM, Sherwood MB, Grehn F. WGA Guidelines on Design and Reporting of Glaucoma Surgical Trials. Kugler Publications; 2009.

21. Lange C, Feltgen N, Junker B, Schulze-Bonsel K, Bach M. Resolving the clinical acuity categories 'hand motion' and 'counting fingers' using the Freiburg Visual Acuity Test (FrACT). Graefes Arch Clin Exp Ophthalmol. 2009;247(1):137-142.

22. Schulze-Bonsel K, Feltgen N, Burau H, Hansen L, Bach M. Visual acuities 'hand motion' and 'counting fingers' can be quantified with the freiburg visual acuity test. Invest Ophthalmol Vis Sci. 2006;47(3):1236-1240.

23. Bach M, Schulze-Bonsel K, Feltgen N, Burau H, Hansen L. Author response: numerical imputation for low vision states [electronic letter]. Invest Ophthalmol Vis Sci. 2007;26.

24. Tassignon MJ, De Groot V, Vervecken F, Van Tenten Y. Secondary closure of posterior continuous curvilinear capsulorhexis in normal eyes and eyes at risk for postoperative inflammation. J Cataract Refract Surg. 1998;24(10):1333-1338.

25. Leysen I, Coeckelbergh T, Gobin L, et al. Cumulative neodymium:YAG laser rates after bag-in-the-lens and lens-in-the-bag intraocular lens implantation: comparative study. J Cataract Refract Surg. 2006;32(12):2085-2090.

26. Pagenstecher $\mathrm{H}$. Mittheilungen aus der Augenheilanstalt zu Wiesbaden: Beiträge zur Lehre vom hämorrhagischen Glaukom. Albrecht von Graefes Archiv für Ophthalmologie. 1871;17(2):98-130.

27. Weiss DI, Shaffer RN, Nehrenberg TR. Neovascular Glaucoma Complicating 
medRxiv preprint doi: https://doi.org/10.1101/2020.01.19.20017889; this version posted January $27,2020$. The copyright holder for this preprint (which was not certified by peer review) is the author/funder, who has granted medRxiv a license to display the preprint in

All rights reserved. No reuse allowed without permission.

Carotid-Cavernous Fistula. Arch Ophthalmol. 1963;69(3):304-307.

28. Stefánsson E. Ocular oxygenation and the treatment of diabetic retinopathy. Surv Ophthalmol. 2006;51(4):364-380.

29. Stefansson E, Landers MB 3rd, Wolbarsht ML. Increased retinal oxygen supply following pan-retinal photocoagulation and vitrectomy and lensectomy. Trans Am Ophthalmol Soc. 1981;79:307-334.

30. Stefansson E, Landers MB 3rd, Wolbarsht ML. Vitrectomy, lensectomy, and ocular oxygenation. Retina. 1982;2(3):159-166.

31. Simpson ARH, Dowell NG, Jackson TL, Tofts PS, Hughes EH. Measuring the effect of pars plana vitrectomy on vitreous oxygenation using magnetic resonance imaging. Invest Ophthalmol Vis Sci. 2013;54(3):2028-2034.

32. Rice TA, Michels RG, Maguire MG, Rice EF. The effect of lensectomy on the incidence of iris neovascularization and neovascular glaucoma after vitrectomy for diabetic retinopathy. Am J Ophthalmol. 1983;95(1):1-11.

33. de Juan E Jr, Hardy M, Hatchell DL, Hatchell MC. The effect of intraocular silicone oil on anterior chamber oxygen pressure in cats. Arch Ophthalmol. 1986;104(7):1063-1064.

34. Rinkoff JS, de Juan E Jr, McCuen BW 2nd. Silicone oil for retinal detachment with advanced proliferative vitreoretinopathy following failed vitrectomy for proliferative diabetic retinopathy. Am J Ophthalmol. 1986;101(2):181-186.

35. Yalvac IS, Eksioglu U, Satana B, Duman S. Long-term results of Ahmed glaucoma valve and Molteno implant in neovascular glaucoma. Eye . 2007;21(1):65-70.

36. Every SG, Molteno ACB, Bevin TH, Herbison P. Long-term results of Molteno implant insertion in cases of neovascular glaucoma. Arch Ophthalmol. 2006;124(3):355-360.

37. Xie Z, Liu H, Du M, et al. Efficacy of Ahmed Glaucoma Valve Implantation on Neovascular Glaucoma. Int J Med Sci. 2019;16(10):1371-1376.

38. Yazdani S, Hendi K, Pakravan M, Mahdavi M, Yaseri M. Intravitreal Bevacizumab for Neovascular Glaucoma: A Randomized Controlled Trial. J Glaucoma. 2009;18(8):632-637.

39. Marra KV, Wagley S, Omar A, et al. Case-matched comparison of vitrectomy, peripheral retinal endolaser, and endocyclophotocoagulation versus standard care in neovascular glaucoma. Retina. 2015;35(6):1072-1083. 
medRxiv preprint doi: https://doi.org/10.1101/2020.01.19.20017889; this version posted January 27, 2020. The copyright holder for this preprint (which was not certified by peer review) is the author/funder, who has granted medRxiv a license to display the preprint in All rights reserved. No reuse allowed without permission. 


\section{Tables}

\section{Table 1}

Table 1 Early and late complications.

\begin{tabular}{l|l|l|l|l}
\hline & \multicolumn{2}{|c|}{ early complications } & \multicolumn{2}{c}{ late complications } \\
& $\mathrm{n}$ & $\%$ & $\mathrm{n}$ & $\%$ \\
\hline hyphema & 18 & 21.7 & 0 & 0.0 \\
fibrinous reaction & 56 & 67.5 & 0 & 0.0 \\
hypopyon & 0 & 0.0 & 0 & 0.0 \\
corneal erosion & 12 & 14.5 & 0 & 0.0 \\
choroidal detachment & 14 & 16.9 & 0 & 0.0 \\
retinal detachment & 1 & 1.2 & 3 & 3.6 \\
phthisis & 0 & 0.0 & 4 & 4.8 \\
hypotony & 0 & 0.0 & 3 & 3.6 \\
\hline
\end{tabular}

Hypotony: IOP $\leq 5 \mathrm{mmHg}$ with hypotonous maculopathy, choroidal folds, or optic neuropathy ${ }^{18}$; phthisis bulbi: IOP $\leq 5 \mathrm{mmHg}$ in a shrunken eye with little or no vision with or without pain containing atrophic and disorganized intraocular structures ${ }^{19}$. 
medRxiv preprint doi: https://doi.org/10.1101/2020.01.19.20017889; this version posted January 27, 2020. The copyright holder for this preprint (which was not certified by peer review) is the author/funder, who has granted medRxiv a license to display the preprint in

All rights reserved. No reuse allowed without permission.

\section{Figures}

Figure 1

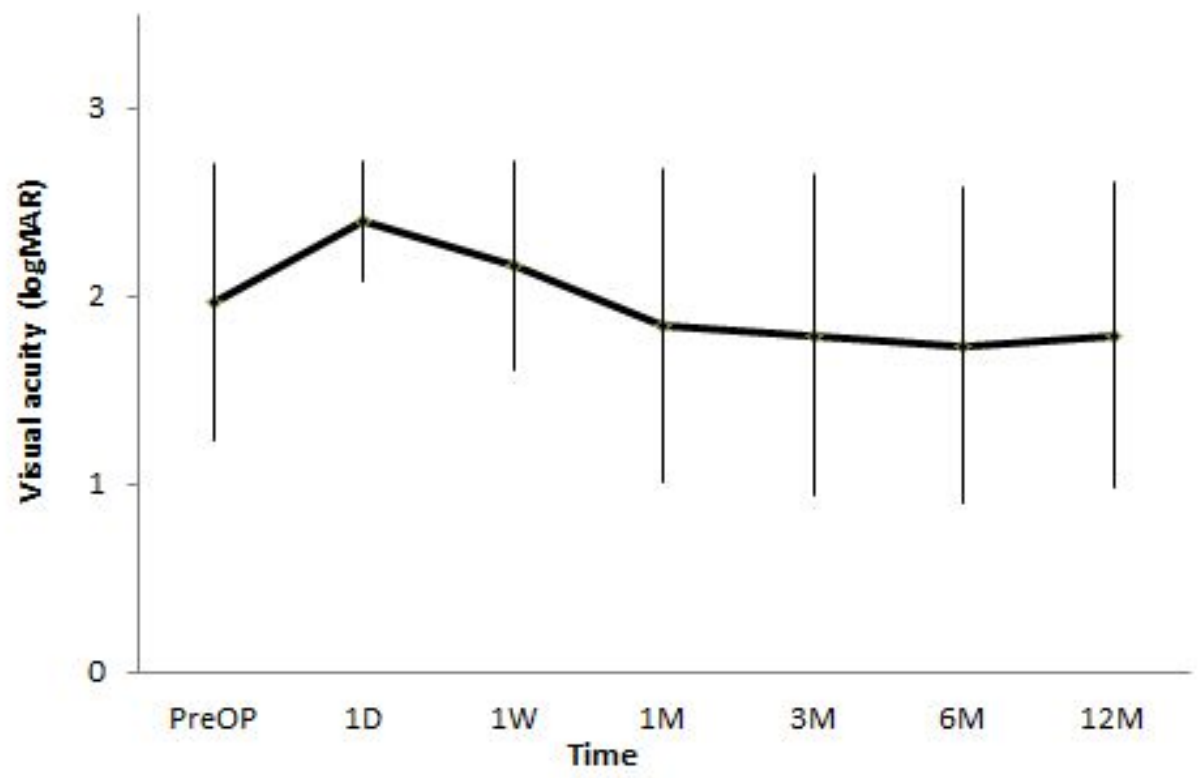

Fig. 1 Diagram of visual acuity during follow-up (mean \pm SD) $(p=0.47)$. 
medRxiv preprint doi: https://doi.org/10.1101/2020.01.19.20017889; this version posted January 27, 2020. The copyright holder for this preprint (which was not certified by peer review) is the author/funder, who has granted medRxiv a license to display the preprint in

All rights reserved. No reuse allowed without permission.

Figure 2

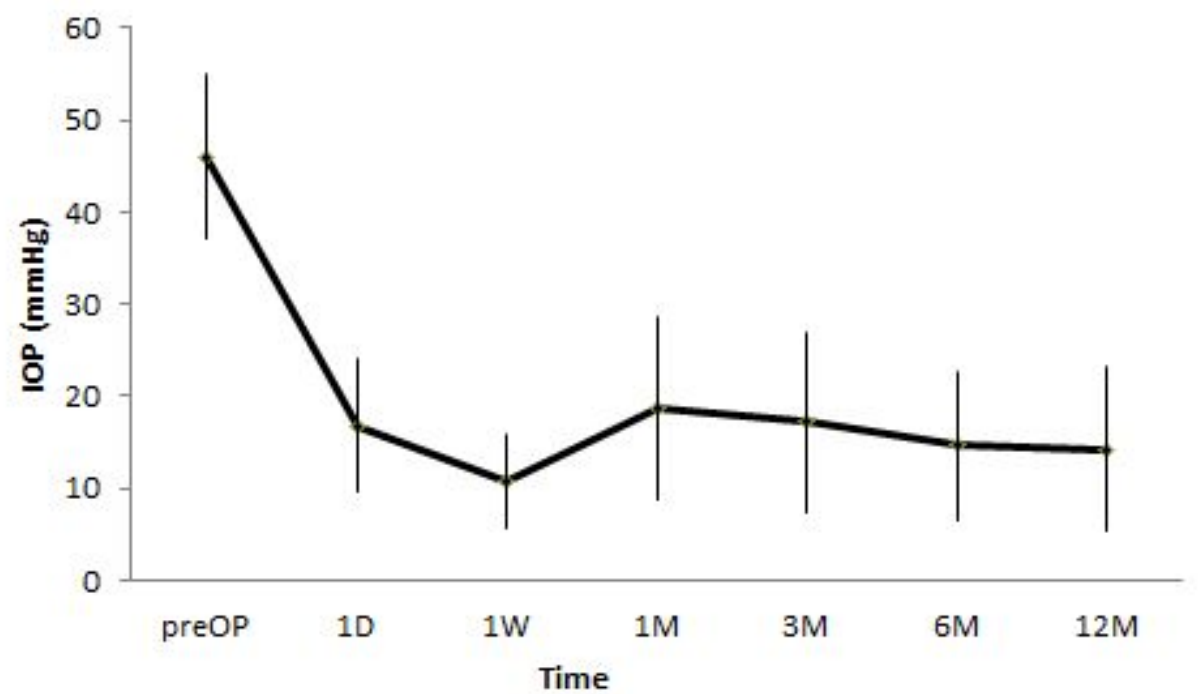

Fig. 2 Diagram of IOP during follow-up (mean $\pm S D)(p<0.001)$. 
medRxiv preprint doi: https://doi.org/10.1101/2020.01.19.20017889; this version posted January 27, 2020. The copyright holder for this preprint (which was not certified by peer review) is the author/funder, who has granted medRxiv a license to display the preprint in

All rights reserved. No reuse allowed without permission.

Figure 3

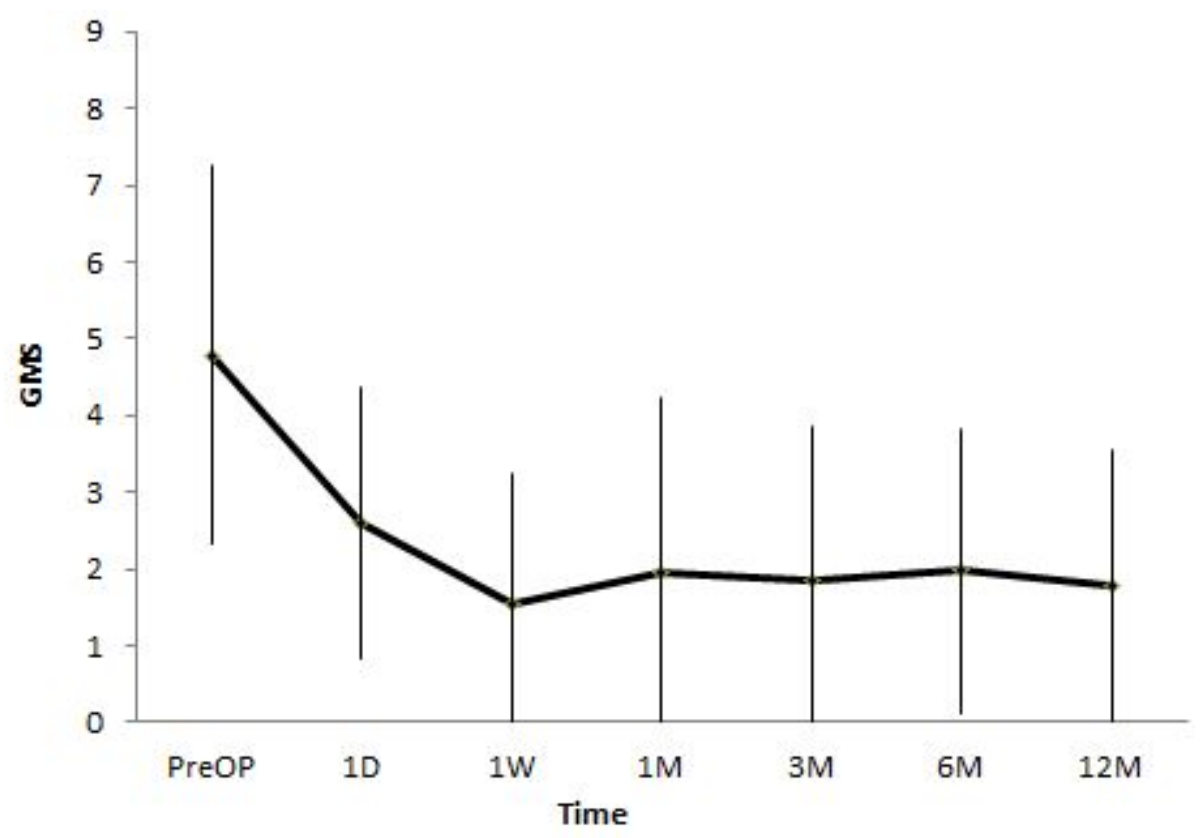

Fig. 3 Diagram of GMS during follow-up (mean $\pm S D)(p<0.001)$. 
medRxiv preprint doi: https://doi.org/10.1101/2020.01.19.20017889; this version posted January $27,2020$. The copyright holder for this preprint (which was not certified by peer review) is the author/funder, who has granted medRxiv a license to display the preprint in

All rights reserved. No reuse allowed without permission.

Figure 4

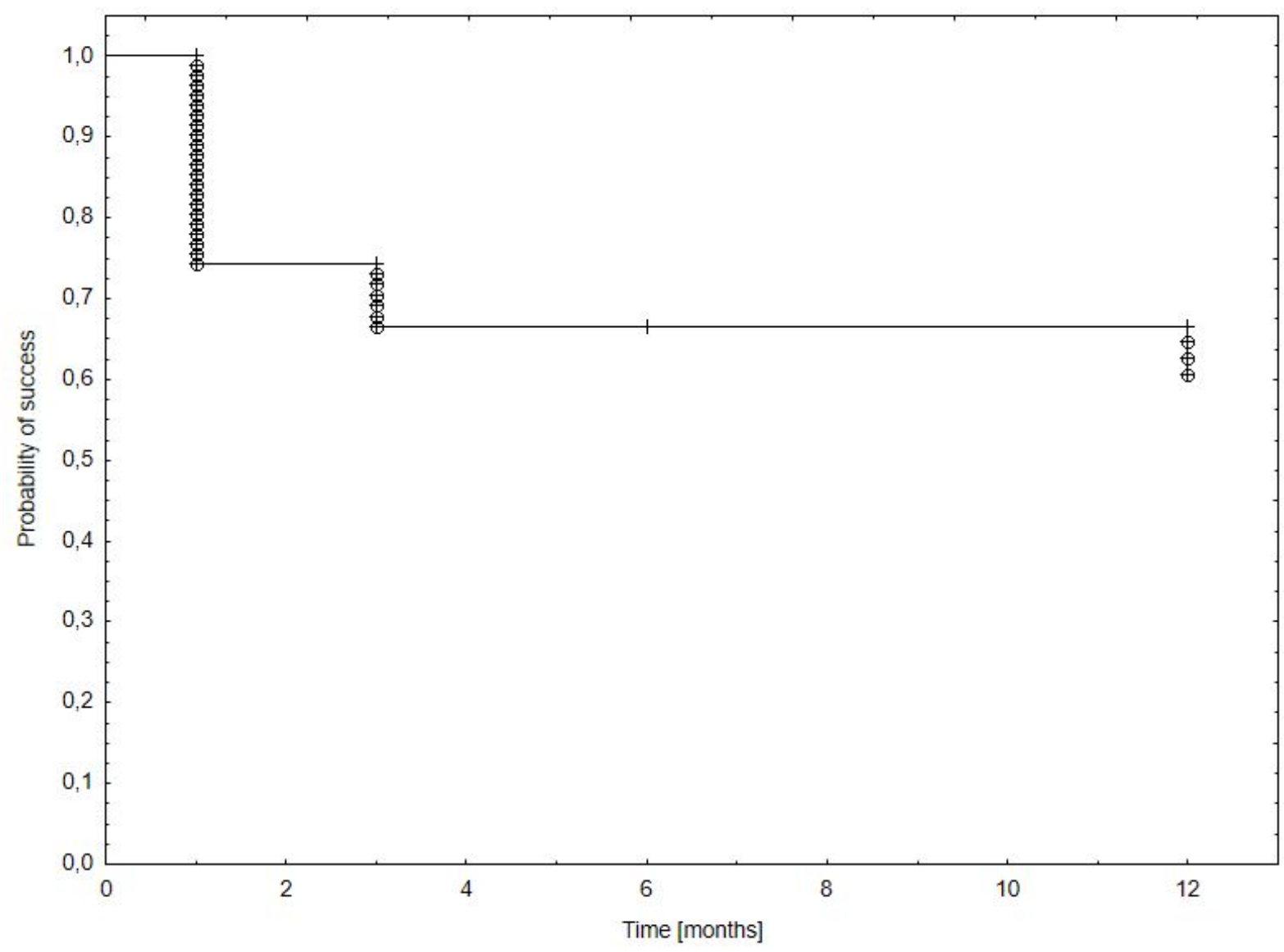

Fig. 4. Kaplan-Meier univariate estimates of the probability of success: IOP $\leq 21 \mathrm{mmHg}$ or IOP reduction $\geq 30 \%$ from baseline, with or without glaucoma medication, without vision loss. 